\title{
Phytochemical, toxicological and antimicrobial evaluation of lawsonia inermis extracts against clinical isolates of pathogenic bacteria
}

\author{
Iram Gull, Maria Sohail, Muhammad Shahbaz Aslam and Muhammad Amin Athar
}

\begin{abstract}
Background: The emerging resistance of pathogen against the currently available antimicrobial agents demands the search of new antimicrobial agents. The use of medicinal plants as natural substitute is the paramount area of research to overwhelm the drug resistance of infectious agents. Scientists have not made enough effort on the evaluation of safety of medicinal plant yet.
\end{abstract}

Methods: In the present study antimicrobial activity of Lawsonia inermis is investigated against clinical isolates of seven bacteria including four Gram negative (Escherichia coli, Salmonella typhi, Klebsiella spp., Shigella sonnei) and three Gram positive (Bacillus subtilis, Staphylococcus aureus, Staphylococcus epidermidis) using disc diffusion method. Four types of Lawsonia inermis extracts were prepared using methanol, chloroform, acetone and water as extraction solvents, while DMSO (Dimethyl sulfoxide) and water as dissolution solvents. The rate and extent of bacterial killing was estimated by time-kill kinetic assay at $1 \times$ MIC of each bacterial isolate. The overall safety of Lawsonia inermis extracts was assessed in mice.

Results: Lawsonia inermis displayed noteworthy antimicrobial activity against both gram positive and gram negative bacterial strains used in the study. The minimum value of MIC for different bacterial strains ranged from $2.31 \mathrm{mg} / \mathrm{ml}$ to $9.27 \mathrm{mg} / \mathrm{ml}$. At $1 \times$ MIC of each bacterial isolate, $3 \log _{10}$ decrease in CFU was recorded after 6 hours of drug exposure and no growth was observed in almost all tested bacteria after 24 hours of exposure. No sign of toxidrome were observed during in vivo toxicity evaluation in mice at $300 \mathrm{mg} / \mathrm{kg}$ concentration.

Conclusion: In conclusion, the present study provides the scientific rational for medicinal use of Lawsonia inermis. The use of Lawsonia inermis extracts is of great significance as substitute antimicrobial agent in therapeutics.

Keywords: Lawsonia inermis, Antimicrobial activity, Time-kill kinetic assay

\section{Introduction}

In traditional herbal medicine, plants have been used for many years [1]. Therefore, plants have attained status of natural source of new and potent antimicrobial agents [2]. Medicinal plants are used as ethnomedicine in different countries around the world [3] and are source of natural products providing unlimited opportunity for new drugs because of readily available medicinal diversity [4].

Lawsonia Inermis (L. inermis) is a scientific name of a tall shrub plant commonly known as Henna or Mehndi

\footnotetext{
* Correspondence: iramgull86@yahoo.com

Institute of Biochemistry and Biotechnology, Quid-i-Azam Campus, University of the Punjab, Lahore 54590, Pakistan
}

\section{Biomed Central}

[5] or mignonette tree [6] belongs to Kingdom: Plantae, Division: Angiospermae, Class: Dicotyledoneae, Order: Myrtales, Family: Lythraceae, Genus: Lawsonia, Species: L. inermis [7]. Henna is a flowering plant, having a height of 5 meters, natal to subtropical and tropical regions of world including South Asia, Africa, oases of Sahara Dessert and even in northern regions of Australia. Leaves of henna plant are entire, opposite, sub-sessile, oval-shaped and smooth [8]. Leaves have length of 2-3 cm with $1-2 \mathrm{~cm}$ width [5]. Henna shrub is highly branched and has greyish-brown barks [9].

Main chemical constituents of henna are Lawsone (2hydroxynaphthoquinone), mucilage, mannite, gallic acid 
and tannic acid [10]. Henna is known to be used as a cosmetic agent for dyeing hair, nails and skin [11].

In traditional medicine, henna plant is used to treat many diseases like oedema, bronchitis, menstrual disorder, rheumatism, hemorrhoids and even in jaundice, leprosy, pain, spleen enlargement, dysentery and skin problems [9,12-14]. Henna can also be used as an astringent and antihemorragic agent and is also known for its hypotensive, cardio inhibitory and sedative effects [9]. In addition, henna is reported to show some other properties including hypoglycemic [15], immunostimulant [16], hepatoprotective [17], anti-inflammatory [18], tuberculostatic [19], anti-cancer and antioxidant properties [20].

The present research is designed to determine the antimicrobial activity of leaves of Lawsonia inermis available locally in Pakistan against certain pathogenic bacterial strains.

\section{Materials and methods Bacterial cultures}

Bacterial cultures used in the present study were clinical isolates collected from the Shaikh Zayed Hospital and Jinnah Hospital, Lahore, Pakistan. The cultures comprise of four Gram negative bacterial isolates namely Escherichia coli, Salmonella typhi, Klebsiella spp., Shigella sonnei and three Gram positive bacterial isolates namely Bacillus subtilis, Staphylococcus aureus, Staphylococcus epidermidis.

\section{Maintenance of bacterial cultures}

All the bacterial isolates were cultured and maintained in LB (Luria Bertani) medium (1\% Tryptone, 1\% sodium chloride, $0.5 \%$ yeast extract) during all the experiments of the study until mentioned. The bacterial cultures were refreshed fortnightly.

\section{Plant material}

The dried leaves of Lawsonia inermis (Henna) used in the present study were purchased from the local market of Lahore, Pakistan.

\section{Preparation of plant extract}

To determine the in vitro antimicrobial activity of Lawsonia inermis, four different types of extracts including methanol extract, aqueous extract, chloroform extract and acetone extract were prepared.

For the preparation of extracts, dried leaves of Henna were ground to fine powder mechanically in electric grinder. Powdered leaves $(10 \mathrm{~g})$ were added in four flasks of $100 \mathrm{ml}$ volume and $50 \mathrm{ml}$ of each solvent was added to each flask separately. The flasks were kept in incubator at $37^{\circ} \mathrm{C}$ overnight with shaking at $180 \mathrm{rpm}$. The contents of flask were first filtered through four layers of muslin cloth and then through Whatman filter paper.
The filtrate was evaporated in rotary evaporator at $50^{\circ} \mathrm{C}$. The weight of residues was recorded. DMSO (Dimethyl sulfoxide) was used to dissolve the residues of methanol, acetone and chloroform extracts while aqueous extract residues were dissolved in distilled water at different concentrations. The resulting extracts were stored at $4{ }^{\circ} \mathrm{C}$ for further use in experiments.

\section{Inoculum preparation}

Before performing antimicrobial activity assay each bacterial strain was refreshed in $5 \mathrm{ml}$ of LB broth ( $\mathrm{pH} 7$ ) separately under sterile conditions. Cultures were incubated in shaking incubator at $160 \mathrm{rpm}$ for 16 hours at $37^{\circ} \mathrm{C}$. Each bacterial culture was maintained at the concentration of $10^{7} \mathrm{CFU} / \mathrm{ml}$.

Antimicrobial sensitivity test using disc diffusion method The assay of antimicrobial activity of Lawsonia inermis extracts was performed by Disc diffusion method [21]. Disc impregnated with DMSO were used as control. The diameter of zones of inhibition formed was measured in $\mathrm{mm}$ (millimeters). The test was performed in triplicate with each bacterial strain and mean zone of inhibition was recorded.

Determination of minimum inhibitory concentration (MIC) MIC of four different extracts of Lawsonia inermis was determined against the test bacterial cultures using the method described by Natta et al. [22] with slight modifications. Briefly, starting from highest concentration of each extract of Lawsonia inermis serial dilution were prepared ranging from 544-17 $\mathrm{mg} / \mathrm{ml}$ for methanol extract, 70$2.18 \mathrm{mg} / \mathrm{ml}$ for chloroform extract, $660-20.65 \mathrm{mg} / \mathrm{ml}$ for aqueous extract and 74.2-2.31 mg/ml for acetone extract. DMSO was used as diluent for all extract except for aqueous extract where water was used instead of DMSO. Sterile discs were dipped in different dilutions for $1 \mathrm{~min}$ and placed on LB agar plates seeded with each bacterial culture separately. The whole experiment was performed under aseptic conditions. Plates were then incubated at $37^{\circ} \mathrm{C}$ for $16 \mathrm{hrs}$. The minimum concentration of each extract with clear zone of inhibition was considered as MIC. The zone of inhibition in each case was measured as the diameter of the clear zone and results were recorded. Each experiment was performed in triplicate.

\section{Phytochemical analysis}

The extracts of Lawsonia inermis prepared in the present study were screened for phytochemicals including carbohydrates, cardioglycosides, terpenoids, tannins, phenolic compounds, proteins and quinones by phytochemical analysis as below [23]. 


\section{Carbohydrates}

$1 \mathrm{ml}$ of each of four different extracts was taken in test tubes separately and treated with $5 \mathrm{ml}$ of Fehling's solution (Solution A: $34.6 \mathrm{~g}$ of copper (II) sulfate pentahydrate dissolved in $500 \mathrm{ml}$ distilled water, Solution B: $125 \mathrm{~g}$ of potassium hydroxide and $173 \mathrm{~g}$ of potassium sodium tartrate tetrahydrate dissolved in $500 \mathrm{ml}$ of distilled water, combine solution A and solution B (1:1) just before use). The test tubes were placed in boiling water bath for $5 \mathrm{~min}$. The tubes were observed for appearance of yellow or red color precipitates indicating the presence of reducing sugars.

\section{Cardioglycosides}

$5 \mathrm{ml}$ of each of the four extracts was taken in test tubes separately and treated with $2 \mathrm{ml}$ of glacial acetic acid having a drop of ferric chloride solution. $1 \mathrm{ml}$ of the concentrated sulphuric acid was added to each test tube. Test tubes were observed for the appearance of brown coloured ring at the interface indicating the presence of cardioglycosides.

\section{Terpenoids}

$5 \mathrm{ml}$ of each of the four extracts was taken in test tubes separately and mixed with $2 \mathrm{ml}$ of chloroform. Concentrated sulphuric acid was added to form a layer. Test tubes were observed for the appearance of reddish brown colour at the interface.

\section{Tannins}

$2 \mathrm{ml}$ of each extract of Lawsonia inermis was mixed with few drops of $0.1 \%$ ferric chloride solution in test tubes separately. Test tubes were observed for the appearance of brownish green colour.

\section{Phenolic compounds}

$1 \mathrm{ml}$ of each extract of Lawsonia inermis was mixed with 4 drops of ethanol and 3 drops of $0.1 \%$ ferric chloride solution in test tube separately. Test tubes were observed for the appearance of red color.

\section{Proteins}

$1 \mathrm{ml}$ of each extract was taken in test tubes separately. 2 drops of freshly prepared $0.2 \%$ ninhydrin reagent $(2.5 \mathrm{~g}$ of ninhydrin dissolved in $50 \mathrm{ml}$ n-butyl alcohol on mild heating and stirring and diluted $500 \mathrm{ml}$ with n-butyl alcohol) were added. Test tubes were heated for few minutes. Test tubes were observed for the appearance of blue color.

\section{Quinones}

Few drops of $1 \mathrm{~N}$ sodium hydroxide solution were mixed with $1 \mathrm{ml}$ of each extract of Lawsonia inermis in test tubes separately. Test tubes were observed for the appearance of red colour indicating the presence of quinones.

\section{Time-Kill kinetic analysis}

The rate of bacterial killing was determined using Lawsonia inermis extracts with least MIC value for each bacterial isolate by time-kill kinetic assay as described by Miyasaki et al. [24] with slight modifications. Briefly, overnight bacterial cultures were diluted to the $5 \times 10^{5} \mathrm{CFU} / \mathrm{mL}$ with LB broth supplemented with $1 \times$ MIC of Lawsonia inermis extract for each bacterial isolate. The cultures were grown at $37^{\circ} \mathrm{C}$ with agitation at $160 \mathrm{rpm}$. The aliquots of cultures were collected at different time intervals $(0 \mathrm{hr}, 1 \mathrm{hr}, 6 \mathrm{hr}$, $12 \mathrm{hrs}, 24 \mathrm{hrs}, 36 \mathrm{hrs}$ and $48 \mathrm{hrs}$ ), serially diluted in LB broth and plated onto LB agar plates. After incubating the plates at $37^{\circ} \mathrm{C}$ for 16 hours viable colonies were enumerated. The results were recorded in terms of $\log _{10} \mathrm{CFU}$ and plotted vs. time for each bacterial isolate.

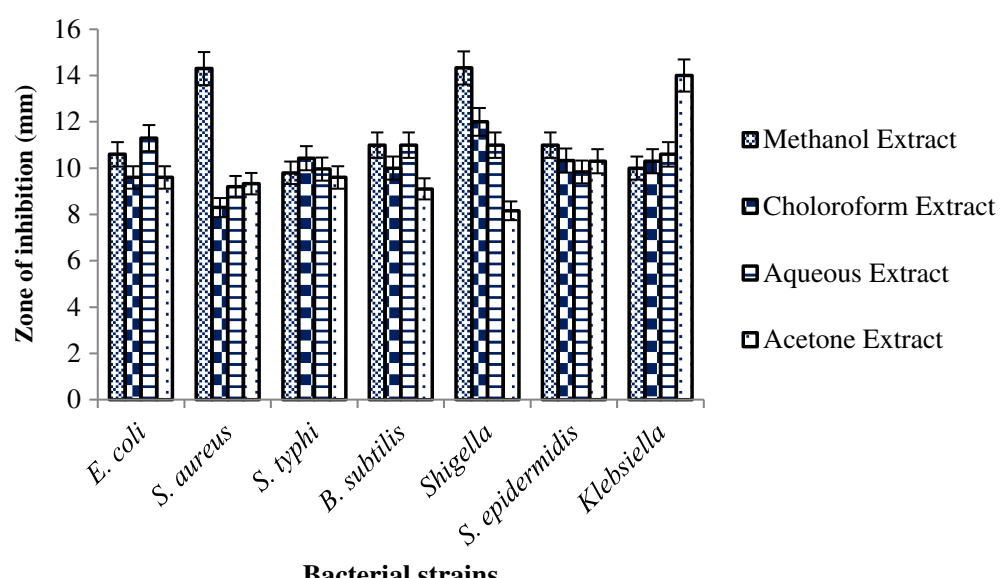

Figure 1 Zone of inhibition $(\mathrm{mm})$ of Lawsonia inermis extracts against tested bacterial isolates. 


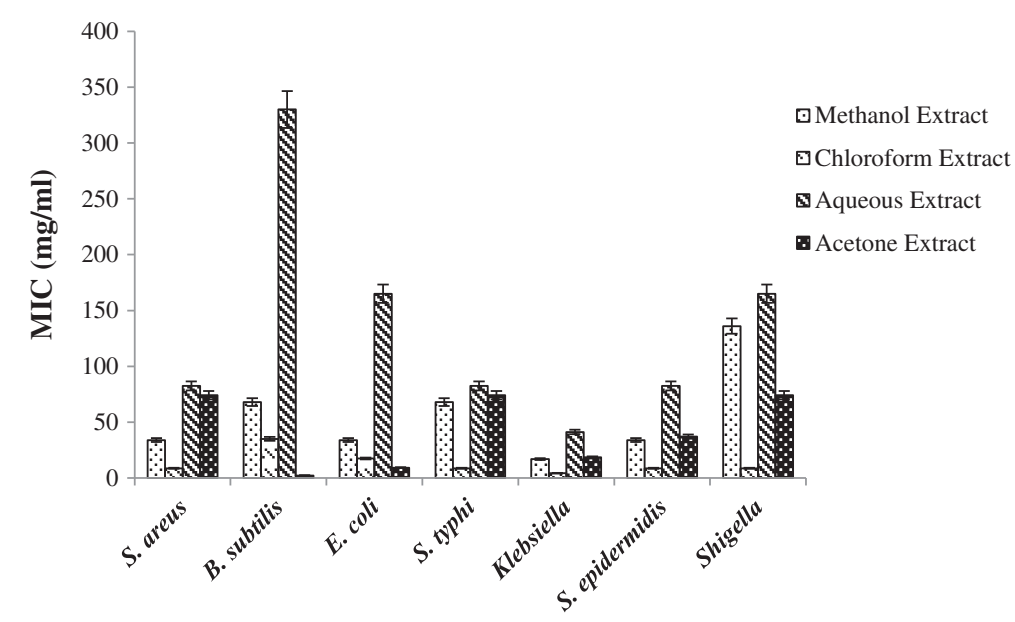

Figure 2 Minimum inhibitory concentration (MIC) of different extracts of Lawsonia inermis against tested bacterial isolates.

Toxicological evaluation of Lawsonia inermis extract

The experiments of acute toxicity in animals were performed in the animal house of Institute of Biochemistry and Biotechnology, University of the Punjab, Lahore, Pakistan after the approval of departmental ethical committee. Each of the two groups comprised of 10 male albino mice (weighing 150-200 g) were used to evaluate the acute toxicity of Lawsonia inermis ethanol extract. The animals were housed in cages and served with proper diet according to the international standards. One group was administered with ethanol extract of Lawsonia inermis $(300 \mathrm{mg} / \mathrm{Kg}$ ) and other group with equal volume of vehicle (DMSO) daily through subcutaneous route for 2 weeks by subcutaneous injection. The animals were continuously observed for signs of toxidromes such as aggression, sedation, rising fur, increased respiration, altered cardiac rate, excitation, convulsion, stupor, vomiting, etc. or death in first 2 hours and then after 24 hours.

\section{Statistical analysis}

Values are mean of \pm standard deviation of three triplicates.

\section{Results and discussion}

Dried leaves of Lawsonia inermis were used to prepare the extracts as it has been reported that dried preparation have more concentrated active phytochemical compounds than fresh plant material [25]. Four different types of extracts were prepared including methanol extract, chloroform extract, aqueous extract and acetone extract. The results revealed that all extracts exhibited antimicrobial activity against all bacterial strains used in the present study. However bacterial strains showed differential sensitivity for each extract (Figure 1). Antimicrobial activity was not observed with controls (DMSO and water). According to the study of Papageorgiou et al. [26], phytochemical constituents of Lawsonia inermis exhibit antimicrobial activity only against gram positive bacteria while ineffective for gram negative bacteria. In our study, it was interested to note that Lawsonia inermis had antimicrobial activity against both gram positive (S. aureus, $B$. subtilis and S. epidermidis) and gram negative (E. coli, S. typhi, Klebsiella spp. and Shigella) bacteria. The studies of Bhuwaneshwari et al. [13]; Habbal et al. [27] and Hussain et al. [28] support our findings.

The values of MIC for each tested bacterial strain had been shown in Figure 2. From the data in Figure 2, it was illustrated that all of the tested bacterial isolates showed minimum value of MIC for chloroform extract except E. coli and B. subtilis. The minimum MIC value of E. coli $(9.27 \mathrm{mg} / \mathrm{ml})$ and B. subtilis $(2.31 \mathrm{mg} / \mathrm{ml})$ was observed using acetone extract. The MIC values of our study were less than the MIC values reported by Al-kurashy et al. [29]. They found MIC values in the range of $8-64 \mathrm{mg} / \mathrm{ml}$ for aqueous extract and 32-64 $\mathrm{mg} / \mathrm{ml}$ for alcoholic extract of Lawsonia inermis against E. coli,

Table 1 Phytochemical analysis of different extracts of Lawsonia inermis

\begin{tabular}{ccccc}
\hline \multicolumn{5}{c}{ Extracts of Lawsonia inermis } \\
\hline & Methanol & Chloroform & Acetone & Aqueous \\
\hline Cardioglycosides & + & + & + & + \\
Terpenoids & + & - & + & + \\
Carbohydrates & + & + & + & + \\
Proteins & - & - & - & - \\
Phenols & + & + & + & + \\
Quinones & + & + & + & + \\
Tannins & + & + & + & + \\
\hline
\end{tabular}

(+ Sign indicating presence of compound; - sign indicating absence of compound). 


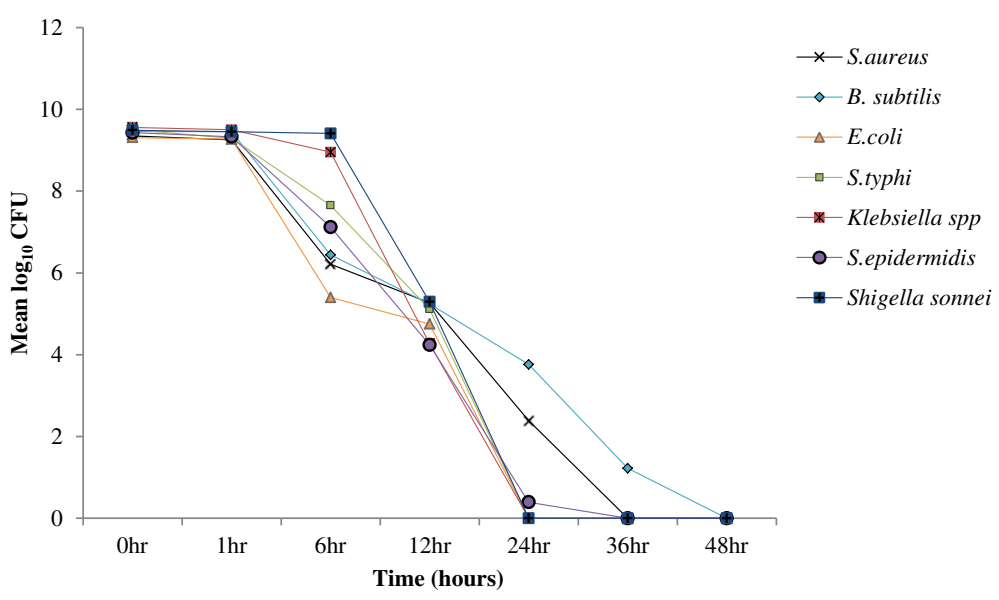

Figure 3 Time-Kill kinetic analysis of tested bacterial isolates.

S. aureus, $P$. aureginosa and E. faecalis. It was established that chloroform extract of Lawsonia inermis was more promising antimicrobial agent for S. aureus, S. epidermidis, S. typhi, Klebsiella spp. and Shigella while its acetone extract for E. coli and B. subtilis at least in in vitro antimicrobial assay.

The secondary metabolites mainly attribute the antimicrobial activity of plants [30]. The active constituents of these secondary metabolites include phenolic compounds and tannins [31]. In order to identify the metabolites present in different extracts of Lawsonia inermis phytochemical analysis were performed. The data in Table 1 depicted that methanol, acetone and aqueous extracts had cardioglycosides, terpenoids, carbohydrates, phenols, quinones and tannins. While proteins were absent in all three of these extracts. The chloroform extract had cardioglycosides, carbohydrates, phenols, quinones and tannins while proteins and terpenoids were absent. These metabolites solubilized in solvent on the bases for polarity. In most of the plant materials, water soluble components includes starches, tannins, saponins, polypeptides, terpenoids, lectins and different ions [32], while alcoholic extract includes flavonol, alkaloids, tannins, sterols polyphenols etc. [33]. Main chemical constituents of henna include Lawsone (2-hydroxynaphthoquinone), mucilage, mannite, gallic acid and tannic acid [10].

The rate of bacterial killing after exposure to the $1 \times$ MIC of respective extract of Lawsonia inermis for each isolate is summarized in Figure 3. The time required to achieve $3 \log _{10}$ decrease in CFU is an acceptable index of bactericidal activity from time-kill analysis [34]. The results illustrated that not a single bacterial isolate showed significant bactericidal activity in first hour. Whereas, $3 \log _{10}$ reduction in viability of all tested bacterial isolates was observed after 12 hours of exposure. The $\log _{10} \mathrm{CFU}$ of all bacterial isolates was reduced to zero after 24 hours of exposure except S. epidermidis (36 hours) and B. subtilis (48 hours).

About $25 \%$ of all medicines available in the market have been derived directly or indirectly from plants $[35,36]$. Herbal medicines are generally believed as safe. However, it is important to evaluate their biological safety before use to avoid fatal consequences [37]. There is no doubt in pharmacological properties of Lawsonia inermis but its toxicological assessment is also indispensable. In vivo acute toxicity of Lawsonia inermis extracts was checked in mice. No mortality was observed during the study. All the signs of toxidrome were negative.

In conclusion, the present study provides the scientific rational for medicinal use of Lawsonia inermis. The use of Lawsonia inermis extracts is of great significance as substitute antimicrobial agent in therapeutics.

\section{Competing interests}

The authors declare that they have no competing interests.

\section{Authors' contributions}

All authors equally participated in designing experiments, acquisition, analysis and interpretation of data. Prof. Dr. M. Amin Athar critical revise the manuscript and approved the final version of manuscript. All authors read and approved the final manuscript.

Received: 3 October 2013 Accepted: 24 November 2013

Published: 1 December 2013

\section{References}

1. Ushimaru PI, Mariama TN, Luiz C, Di Luciano B, Ary FJ: Antibacterial activity of medicinal plant extract. Braz J Microbial 2007, 38:717-719.

2. Blanks T, Brown S, Cosgrave B, Woody J, Bentley V, O' Sullivan N, et al: The Body Shop Book of Wellbeing Mind, Body, and Soul. London: Ebury Press; 1998:173-192.

3. Srivastava J, Lambert J, Vietmeyer N: Medicinal Plants: An Expanding Role in Development, World Bank Technical Paper. No. 320.; 1996.

4. Cos PJ, Arnold V, Dirk VB, Louis M: Anti-infective potential of natural products: How to develop a stronger in vitro proof-of-concept. J Ethnopharmacol 2006, 106:290-302. 
5. Muhammad HS, Muhammad S: The use of Lawsonia inermis Linn. (henna) in the management of burn wound infections. Afri J biotechnol 2005, 4:934.

6. Bailey LH, Bailey EZ, and the staff of the Liberty Hyde Bailey Hortorium: Hortus Third: A Concise Dictionary of Plants Cultivated in the United States and Canada, Macmillan, New York. 1976.

7. Jiny VK, Silvipriya KS, Resmi S, Jolly Cl: Lawsonia inermis (henna): a natural Dye of various therapeutic uses - a review. Inventi Impact: Cosmeceuticals. Article ID-Inventi: Cc/3/10, 2010

8. Ashnagar A, Shiri A: Isolation and characterization of 2-hydroxy-1,4naphthoquinone (lawsone) from the powdered leaves of henna plant marketed in Ahwaz city of Iran. / J Chemtech Res 2011, 3:1941-1944.

9. Rahmoun MN, Benabdallah M, Villemin D, Boucherit K, Mostefa-Kara B, Ziani-Cherif C, Choukchou-Braham N: Antimicrobial screening of the Algerian Lawsonia inermis (henna). Der Pharma Chemica 2010, 6:320-326.

10. Al-Rubiay KK, Jaber NN, Al-Mhaawe BH, Alrubaiy LK: Antimicrobial efficiency of Henna extract. Oman Med J 2008, 2008(23):253-256.

11. Hanna R, Maciej JN, Lapinsky L, Adamowicz L: Molecular structure and infra-red spectra of 2-hydroxy-1,4-naphthaquinone; Experimental matrix isolation and theoretical Hatree-Fock and post Hatree-Fock study. Spec Act 1998, 1998(54):1091-1103.

12. Cuong NX, Binh PT, Thuy MTT, Nami NH, Anh HLT, Dati NT, Thao NP, Kiem PV, Huong LM: Isolation of Lawsonia inermis leaves and synthesis of its dimer derivative by cyclic voltammetry. J Chem 2009, 47:228-232.

13. Bhuvaneshwari K, Poongothai SG, Kuruvilla A: Appala raju B: Inhibitory concentrations of Lawsonia inermis dry powder for urinary pathogens. Indian J Pharmacol 2002, 34:260-263.

14. Warrier PK, Nambiar VP, Ramankutty C: Indian medicinal plants a compoundium of 500 species. Chennai: Orient Longmann Pvt. Ltd 1995 3:303.

15. Syamsudin I, Winarno $H$ : The effect of Inai (Lawsonia inermis) leaves extract on blood sugar level: an experimental study. Res J Pharmacol 2008, 2:20-23.

16. Mikhaeil BR, Badria FA, Maatooq GT, Amer MMA: Antioxidant and immunomodulatory constituents of henna leaves. Z Naturforschung Sec C J Biosci 2004, 59:468-476.

17. Chaudary GD, Poonia P, Kamboj P, Kalia AN: Hepatoprotective protection of Lawsonia inermis L, (seeds). I J phytopharmacol 2012, 3:66-73.

18. Singh S, Shrivastava NM, Modi NT, Saifi AQ: Antiinflammatory activity of Lawsonia inermis. Curr Sci 1982, 51:470-471.

19. Sharma VK: Tuberculostatic activity of henna (Lawsonia inermis Linn.). Tubercle 1990, 71:293-295.

20. Kamal M, Jawaid T: Pharmacological activities of lawsonia inermis Linn.: a review. I J Biomed Res 2010, 2:62-68.

21. Kirby-Bauer $A$ : Antimicrobial sensitivity testing by agar diffusion method. J Clin Pathol 1996, 44:493.

22. Natta L, Orapin K, Krittika N, Pantip B: Essential oil from five Zingiberaceae for anti-food-borne bacteria. Int Food Res J 2008, 15:337-346.

23. Thenmozhi M, Sivaraj R, Hiranmai YR: A comparative phytochemical analysis of Alstonia scholaris, Lawsonia inermis, Ervatamia divaricata and Asparagus racemosus. Int J Pharma Res Dev 2010, 2:86-91.

24. Miyasaki Y, Rabenstein JD, Rhea J, Crouch ML, Mocek UM, Kittel PE, Morgan MA, Nichols WS, Benschoten MMV, Hardy WD, Liu GY: Isolation and characterization of antimicrobial compounds in plant extracts against multidrug-resistant Acinetobacter baumannii. PLOS ONE 2013, 8:e61594.

25. Romero CD, Chopin SF, Buck G, Martinez E, Garcia M, Bixby L: Antibacterial properties of common herbal remedies of the southwest. J Ethnopharmacol 2005, 99:253-257.

26. Papageorgiou VP, Assimopoulou AN, Couladouros EA, Hepworth D, Nicolaou KC: The chemistry and biology of alkannin, shikonin, and related naphthazarin natural products. Angew Chem 1999, 38:270-300.

27. Habbal OA, Al-Jabri AA, El-Hag AH, Al-Mahrooqi ZH, Al-Hashmi NA: In-vitro antimicrobial activity of lawsonia inermis Linn (henna): a pilot study on the Omani henna. Saudi Med J 2005, 26:69-72.

28. Hussain T, Arshad M, Khan S, Sattar H, Qureshi MS: In vitro screening of methanol plant extracts for their antibacterial activity. Pak J Bot 2011, 43:531-538.

29. Al-kurashy HMK, Ai-windy SA, Al-buhadilly AK: Evaluation of the antimicrobial activity of Lawsonia inermis: in vitro study. Iraqi J Sci 2011, 52:16-19.
30. Gonzalez-Lamothe R, Mitchell G, Gattuso M, Moussa S, Malouin DF, Bouarab K: Plant antimicrobial agents and their effects on plant and human pathogens. Int J Mol Sci 2009, 10:3400-3419.

31. Edwin $\mathrm{H}$ : Natural polyphenols (vegetable tannins) as drugs: possible modes of action. J Nat Prod 1996, 2:205-215.

32. Darout I, Cristy A, Skaug N, Egeberg P: Identification and quantification of some potential antimicrobial anionic components in miswak extract. Ind J Phar 2000, 32:11-14.

33. Ivanovska N, Philipov S, Istatkova R, Georgieve P: Antimicrobial and immunological activity of ethanol extracts and fractions Isopyrum thalictroides. J Ethnopharmacol 1996, 54:143-151.

34. National Committee for Clinical Laboratory Standards: Methods for Determining Bactericidal Activity of Antimicrobial Agents. Approved Standard M26-A. Wayne, PA: National Committee for Clinical laboratory Standards; 1999.

35. De Smet PA: The role of plant-derived drugs and herbal medicines in healthcare. Drugs 1997, 54:801-840.

36. WHO: WHO Global Atlas of Traditional, Complementary and Alternative Medicine. 2005th edition. Geneva: World Health Organization; 2005:1-2.

37. Kunle OF, Egharevba HO, Ahmadu PO: Standardization of herbal medicines - a review. Int J Biodivers Conserv 2012, 4:101-112.

doi:10.1186/1476-0711-12-36

Cite this article as: Gull et al:: Phytochemical, toxicological and antimicrobial evaluation of lawsonia inermis extracts against clinical isolates of pathogenic bacteria. Annals of Clinical Microbiology and Antimicrobials 2013 12:36.

\section{Submit your next manuscript to BioMed Central and take full advantage of:}

- Convenient online submission

- Thorough peer review

- No space constraints or color figure charges

- Immediate publication on acceptance

- Inclusion in PubMed, CAS, Scopus and Google Scholar

- Research which is freely available for redistribution 